\title{
PELAKSANAAN MODEL PENGEMBANGAN KINERJA GURU PADA SMA NEGERI DI KOTA PALOPO
}

\author{
Oleh: Hilal Mahmud \\ Fakultas Tarbiyah dan IImu Keguruan IAIN Palopo \\ Email: hilalmahmud@iainpalopo.ac.id
}

\begin{abstract}
Abstrak
Tujuan penelitian ini adalah untuk mengungkap: (1) model pengembangan kinerja guru pada SMA Negeri di Kota Palopo; (2) pelaksanaan model pengembangan kinerja guru melalui supervisi pendidikan pada SMA Negeri di Kota Palopo; dan (3) Pelaksanaan model pengembangan kinerja guru melalui pemberdayaan pada SMA Negeri di Kota Palopo. Penelitian ini termasuk jenis penelitian lapangan yang kajiannya bersifat kualitatif-verifikatif untuk mengungkap makna yang ada di balik fenomena realitas sosial tentang pelaksanaan model pengembangan kinerja guru pada SMA Negeri di Kota Palopo. Pendekatan yang digunakan adalah pendekatan fenomenologi dalam upaya memahami fenomena-fenomena yang berkaitan dengan realitas, situasi, kondisi, dan interaksi yang terjadi dalam pelaksanaan model pengembangan kinerja guru pada SMA Negeri di Kota Palopo. Metode pengumpulan data yang digunakan dalam penelitian ini adalah wawancara, observasi, dan dokumentasi. Hasil penelitian ini menunjukkan bahwa: (1) Model pengembangan kinerja guru yang diterapkan di SMA Negeri di Kota Palopo adalah model pengembangan kinerja guru melalui supervisi pendidikan; (2) Pelaksanaan model pengembangan kinerja guru pada SMA Negeri di Kota Palopo belum berjalan optimal karena sejumlah kelemahan, yaitu: (a) perencanaan baru sebatas penjadualan kegiatan serta belum dibuat khusus dan detail berdasarkan analisis kebutuhan; (b) pembinaan dan pendampingan belum optimal dan belum fokus pada kebutuhan guru; dan (3) Pelaksanaan model pengembangan kinerja guru melalui pemberdayaan baru sebatas memenuhi kebutuhan persyaratan kenaikan pangkat. Potensi guru belum dimanfaatkan melalui pemberdayaan.
\end{abstract}

\section{Kata Kunci: Pelaksanaan Model, Pengembangan, Kinerja Guru}

\section{A. PENDAHULUAN}

Dalam upaya mengoptimalkan pelaksanaan tugas guru agar menampilkan kinerja yang mendukung upaya peningkatan mutu pendidikan maka program pengembangan kinerja guru menjadi suatu keniscayaan. Berdasarkan observasi awal peneliti ke beberapa SMA Negeri di kota Palopo, ditemukan fakta berikut ini. Pertama, program pengembangan kinerja guru masih belum optimal. Selain itu Penelitian Tindakan Kelas dan lesson study belum dilaksanakan secara optimal. Padahal, pengembangan 
profesi guru dapat dilakukan melalui lesson study dan Penelitian Tindakan Kelas. Kedua, pada umumnya guru belum memanfaatkan penggunaan aplikasi berbagai media pembelajaran berbasis Teknologi Informasi (Information Technology). Ketiga, Musyawarah Guru Mata Pelajaran (MGMP) sebagai wadah tempat para guru mata pelajaran sejenis berkumpul, saling berbagi informasi, serta menjadi tempat guru meningkatkan dan mengembangkan kinerjanya, belum dimanfaatkan secara optimal.

Persyaratan yang begitu tinggi dan ketat dalam pencapaian kategori sekolah yang memiliki keunggulan baik input, proses, maupun output sebagaimana dipersyaratkan sebagai sekolah masa depan, diperhadapkan dengan situasi dan kondisi faktual yang dikemukakan di atas, khususnya SMA Negeri di Kota Palopo yang masih dalam taraf "berjuang keras" untuk mengembangkan diri agar dapat mendekati persyaratan sekolah unggul masa depan. Situasi ini menarik dan menjadi isu mendasar yang berusaha diungkap untuk menjadi bahan kajian dan estimasi pola pengembangan kinerja guru yang lebih ideal bagi sekolah di kota Palopo, bahkan di Indonesia.

Berdasarkan latar belakang yang telah diuraikan di atas maka rumusan masalah dalam penelitian ini adalah: (1) bagaimana model pengembangan kinerja guru pada SMA Negeri di Kota Palopo?; (2) bagaimana pelaksanaan model pengembangan kinerja guru melalui supervisi pendidikan pada SMA Negeri di Kota Palopo?; dan (3) bagaimana pelaksanaan model pengembangan kinerja guru melalui pemberdayaan pada SMA Negeri di Kota Palopo. Hasil penelitian ini diharapkan dapat: (1) memberi kontribusi bagi organisasi sekolah dalam merancang dan melaksanakan model pengembangan kinerja guru; (2) sebagai bahan pertimbangan dalam memutuskan tindakan dan kebijakan program peningkatan mutu pendidikan yang mampu menumbuhkembangkan manajemen sekolah/madrasah yang kondusif menuju sekolah/madrasah masa depan; dan (2) Sebagai bahan pertimbangan dalam memutuskan tindakan program pengembangan kinerja guru yang mampu mengantisipasi perubahan.

\section{B. KAJIAN TEORETIS}

\section{Kinerja Guru dan Faktor yang Berpengaruh Terhadap Kinerja Guru}

Kinerja merupakan terjemahan dari kata "performance" berarti pertunjukan, perbuatan, daya guna, hasil, prestasi, pelaksanaan. "Performance" berasal dari kata "to 
perform" berarti melakukan, menyelenggarakan, dan memainkan. Wibowo mengemukakan bahwa Armstrong dan Bacon memberikan arti "performance" sebagai kinerja, hasil kerja atau prestasi kerja. Kinerja adalah tentang apa yang dikerjakan dan bagaimana cara mengerjakannya. Kinerja juga merupakan hasil pekerjaan yang mempunyai hubungan kuat dengan tujuan strategis organisasi, kepuasan konsumen dan memberikan kontribusi ekonomi. Uhar Suharsaputra menyimpulkan bahwa kinerja merupakan suatu kemampuan kerja atau prestasi kerja yang diperlihatkan oleh seorang pegawai untuk memperoleh hasil kerja yang optimal. ${ }^{1}$ Dengan demikian, kinerja dapat dimaknai sebagai penampilan kerja atau prestasi kerja yang ditunjukkan seorang pegawai untuk memperoleh hasil kerja yang optimal sesuai dengan tujuan organisasi.

Robin Stuart-Kottze mengemukakan bahwa dalam realitas terdapat pula perilaku yang mempunyai konsekuensi negatif dan menurunkan kinerja, yaitu performance blocking behavior. Blocking behavior merupakan perilaku yang menghalangi perubahan, mengalahkan visi, dan merintangi pencapaian tujuan dan sasaran. ${ }^{3}$ Performance blocking behavior disebabkan oleh tekanan dan pengaruh eksternal, berupa ketidakpastian, kecemasan, tantangan, sikap meremehkan, kurangnya kekuasaan dan kontrol. Aspek yang kurang menguntungkan dari blocking behavior tidak hanya sekedar bahwa beberapa individu membuang waktu dan energi untuk melakukan hal yang kontra produktif, tetapi juga pengaruh negatif perilaku yang mereka miliki menular kepada orang lain. Untuk mengurangi pengaruh performance blocking behavior, cara terbaik adalah dengan mendapatkan umpan balik dari pekerja atau melalui kuesioner dan menyediakan cukup waktu dan usaha untuk menemukan akar masalah dan penyebabnya.

Kinerja guru adalah suatu kemampuan kerja dan prestasi kerja yang ditampilkan oleh guru dalam melaksanakan tugasnya. Pandangan ini sejalan dengan pandangan Supardi yang mengemukakan bahwa kinerja guru merupakan kemampuan dan keberhasilan guru dalam melaksanakan tugas-tugas pembelajaran. Supardi mengemukakan bahwa kinerja guru ditunjukkan oleh dimensi: (1) kemampuan menyusun rencana pembelajaran; (2) kemampuan melaksanakan pembelajaran; (3) kemampuan melaksanakan hubungan antar pribadi; (4) kemampuan melaksanakan penilaian hasil belajar; (5) kemampuan melaksanakan program pengayaan; dan (6) kemampuan melaksanakan program remedial. ${ }^{4}$ Kemampuan menyusun rencana 
pembelajaran dengan indikator: (a) merencanakan pengelolaan pembelajaran; (b) merencanakan pengorganisasian bahan pelajaran; (c) merencanakan pengelolaan kelas; (d) merencanakan penilaian hasil belajar. Kemampuan melaksanakan pembelajaran dengan indikator: (a) memulai pembelajaran; (b) mengelola pembelajaran; (c) mengorganisasikan pembelajaran; (d) melaksanakan penilaian proses dan hasil belajar; $\quad$ (e) mengakhiri pembelajaran. Kemampuan melaksanakan hubungan antarpribadi dengan indikator: (a) mengembangkan sikap positif peserta didik; (b) menampilkan kegairahan dalam pembelajaran; (c) mengelola interaksi perilaku dalam kelas. Kemampuan melaksanakan penilaian hasil belajar dengan indikator: (a) merencanakan penilaian; (b) melaksanakan penilaian; (c) mengelola dan memeriksa hasil penilaian; (d) memanfaatkan hasil penilaian; $\quad$ (e) melaporkan hasil penilaian. Kemampuan melaksanakan program pengayaan dengan indikator: (a) memberikan tugas; (b) memberikan bahan bacaan; (c) tugas membantu guru. Kemampuan melaksanakan program remedial dengan indikator: (a) memberikan bimbingan khusus; dan (b) penyederhanaan.

Ada banyak faktor yang berpengaruh terhadap kinerja guru. Untuk memahami faktor-faktor tersebut maka teori kinerja Gibson patut dikemukakan disini. Gibson et al. mengemukakan tiga faktor yang berpengaruh terhadap kinerja, yaitu: variabel individu, variabel organisasi, dan variabel psikologis. ${ }^{7}$ Variabel individu, meliputi kemampuan, keterampilan, mental fisik, latar belakang keluarga, tingkat sosial, pengalaman, demografi (umur, asal usul, jenis kelamin). Variabel organisasi, meliputi sumber daya, kepemimpinan, imbalan, struktur desain pekerjaan. Variabel psikologis, meliputi persepsi, sikap, kepribadian, belajar, dan motivasi. Sementara itu, Sutermeister mengemukakan bahwa kinerja memengaruhi produktivitas. Produktivitas itu sendiri ditentukan oleh kinerja pegawai (employee performance) dan teknologi (technology). Sedangkan kinerja pegawai itu sendiri tergantung pada dua hal yaitu kemampuan dan motivasi. Hersey et. al. menjelaskan bahwa "the motivation of people depends on the strength of their motives. Motives are sometimes defines as needs, wants or impulses within the individual". Ini berarti motivasi tergantung pada kekuatan motif. Motif kadang-kadang didefinisikan sebagai kebutuhan, keinginan atau gerak hati dalam diri individu. Kadarisman menyimpulkan pandangan Hersey 
et.al. bahwa motivasi tidak terlepas dari faktor pendorong (motif) yang seringkali diidentikkan dengan kebutuhan atau keinginan. ${ }^{8}$

Dengan menggunakan kerangka berpikir teori Gibson, Supardi mengelompokkan faktor yang berpengaruh terhadap kinerja guru kedalam lima komponen, yaitu: (1) komponen raw input, meliputi kemampuan memahami kurikulum dan keterampilan mengembangkan dan mengimplementasikan kurikulum; (2) komponen instrumental input, yaitu supervisi kepala sekolah dalam rangka meningkatkan kemampuan guru mengembangkan kurikulum, observasi, dan meningkatkan profesionalitas guru; (3) komponen inveronmental input, yaitu iklim kerja yang kondusif untuk memelihara agar para guru merasa nyaman, berpuas hati, memiliki keyakinan, tidak merasa tertekan, memberikan perhatian kepada kemajuan peserta didik, kepala sekolah memiliki keyakinan akan kinerjanya, peserta didik merasa nyaman dan belajar sungguh-sungguh; (4) komponen proses, meliputi kegiatan: merencanakan pembelajaran, melaksanakan pembelajaran, membina hubungan dengan peserta didik, melakukan penilaian hasil belajar, melaksanakan remedial, dan melaksanakan pengayaan; (5) komponen output, meliputi: kemampuan merencanakan pembelajaran, kemampuan melaksanakan pembelajaran, kemampuan membina hubungan dengan peserta didik, kemampuan melakukan penilaian hasil belajar, kemampuan melaksanakan remedial, dan kemampuan melaksanakan pengayaan. ${ }^{10}$ Dalam penelitian ini penilaian kinerja yang digunakan oleh supervisor hanya melihat faktor atau komponen proses, meliputi kegiatan: merencanakan pembelajaran, melaksanakan pembelajaran, membina hubungan dengan peserta didik, melakukan penilaian hasil belajar, melaksanakan remedial, dan melaksanakan pengayaan.

Mengembangkan setiap guru menjadi self-leader yang efektif adalah tantangan yang menarik dan berat. Kepala sekolah ditantang untuk mampu memimpin dan memberi motivasi kepada para guru yang dipimpinnya untuk mentransfer tanggungjawab yang dibebankan kepadanya sekaligus memimpin diri mereka sendiri dalam melaksanakan tanggungjawab itu. Kekuatan kepala sekolah sebagai Superleader dapat ditunjukkan pada kemampuannya menimbulkan komitmen pada para guru yang dipimpinnya terhadap visinya. Kepala sekolah dan para guru seyogyanya meyakini bahwa mereka adalah umat terbaik, sebagaimana firman Allah swt. dalam QS. Ali 'Imran/3:110, sebagai berikut: 


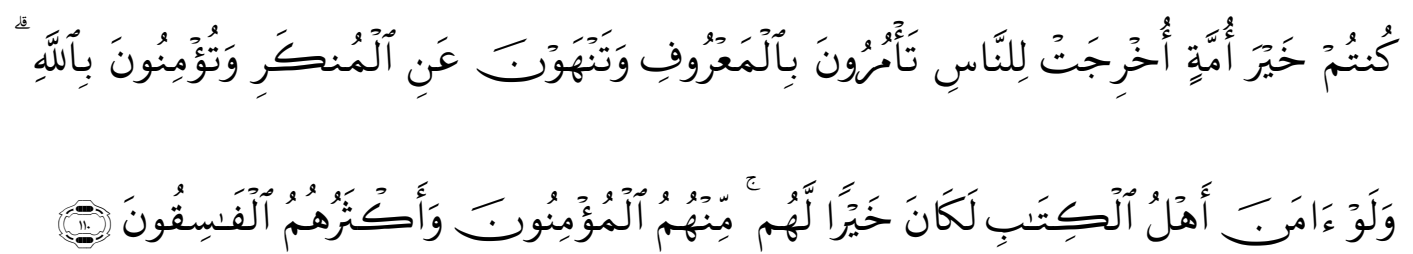

Terjemahnya:

Kamu adalah umat yang terbaik yang dilahirkan untuk manusia, menyuruh kepada yang ma'ruf, dan mencegah dari yang mungkar, dan beriman kepada Allah. ${ }^{14}$

Untuk mendorong para guru menjadi self-leader, keteladanan Rasulullah saw. patut dijadikan inspirasi para kepala sekolah. Sifat Rasulullah yang menginspirasi ini dapat dibaca dalam QS. Al-Ah\}za>b/33:21, sebagai berikut:

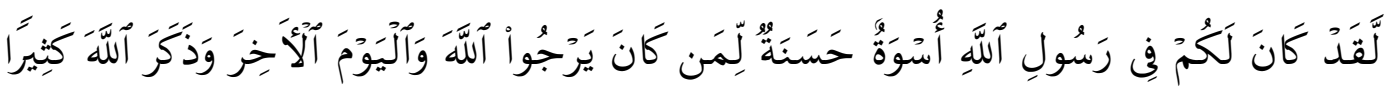

Terjemahnya:

Sesungguhnya telah ada pada (diri) Rasulullah itu suri teladan yang baik bagimu (yaitu) bagi orang yang mengharap (rahmat) Allah dan (kedatangan) hari kiamat dan dia banyak menyebut Allah. ${ }^{15}$

\section{Model Pengembangan Kinerja Guru}

Kata "model" dalam Kamus Besar Bahasa Indonesia berarti pola (contoh, acuan, ragam) dari sesuatu yang akan dibuat atau dihasilkan. ${ }^{16}$ Definisi model dikemukakan secara beragam oleh para pakar. Snelbecker, sebagaimana dikutip Muhammad Yaumi, mengatakan bahwa model is a concretization of a theory which is meant to be analogous to or representative of the process and variables involved in the theory (model adalah konkretisasi/perwujudan teori yang dimaksudkan untuk menjadi analog atau wakil dari proses dan variabel yang terlibat dalam teori). Yaumi menjelaskan bahwa model merupakan sesuatu yang berwujud dalam bentuk fisik atau penjabaran teori untuk dijadikan acuan dalam menjalankan sesuatu. Prawiradilaga mengartikan model sebagai tampilan grafis, prosedur kerja yang teratur dan sistematis, serta mengandung pemikiran bersifat uraian atau penjelasan berikut saran. ${ }^{17}$ Dari berbagai pandangan yang 
dikemukakan di atas, dapat disimpulkan bahwa model adalah pola/bentuk atau prosedur kerja yang teratur dan sistematis yang dijadikan acuan dalam menjalankan sesuatu.

Pengembangan juga merupakan salah satu prinsip dasar manajemen kinerja. ${ }^{18}$ Terdapat beberapa pandangan para pakar tentang pengembangan. R. Wayne Mondy dan Robert M. Noe memandang bahwa: "Development involves learning that goes beyond today's job and has a more long-term focus. It prepares employees to keep pace with the organization as it changes and grows."19 Pandangan Mondy dan Noe ini memberikan gambaran bahwa pengembangan merupakan pembelajaran atau upaya peningkatan pengetahuan yang dituntut dalam pekerjaannya dan fokus pada kepentingan jangka panjang. Pengembangan merupakan upaya mempersiapkan karyawan melaksanakan tugasnya pada organisasi atau lembaga yang senantiasa mengalami perubahan dan pertumbuhan.

Merujuk pada pengertian model, pengembangan dan kinerja di atas maka model pengembangan kinerja dapat diartikan sebagai pola/bentuk atau prosedur kerja yang teratur dan sistematis yang dijadikan acuan dalam menjalankan yang dilakukan oleh organisasi atau lembaga pendidikan agar pengetahuan, kemampuan, dan keterampilan karyawan/tenaga pendidik sesuai dengan tuntutan pekerjaan mereka dalam menunjukkan kemampuan dan keberhasilan mereka melaksanakan tugas-tugas. Model pengembangan kinerja guru merupakan prosedur kerja yang teratur dan sistematis yang dilakukan oleh organisasi atau lembaga pendidikan agar kompetensi tenaga pendidik sesuai dengan tuntutan tugas profesionalnya. Model pengembangan kinerja guru dapat dilakukan melalui layanan supervisi pendidikan dan atau melalui melalui Penelitian Tindakan Kelas (PTK) dan Musyawarah Guru Mata Pelajaran (MGMP).

Dadang Suhardan memandang bahwa supervisi merupakan pengawasan profesional dalam bidang akademik, dijalankan berdasarkan kaidah-kaidah keilmuan tentang bidang kerjanya yang menuntut kemampuan ilmu pengetahuan yang mendalam serta kesanggupan untuk melihat peristiwa pembelajaran dengan misi utama memberi pelayanan kepada guru untuk mengembangkan mutu pembelajaran. Bordman et al., sebagaimana dikutip Supardi, menjelaskan bahwa supervisi pendidikan adalah suatu usaha mendorong, mengkoordinasikan dan membimbing secara kontinu pengembangan guru-guru di sekolah baik individu maupun kelompok agar lebih efektif dalam 
mewujudkan seluruh fungsi pembelajaran. ${ }^{24}$ Pandangan yang dikemukakan di atas menunjukkan bahwa supervisi pendidikan bukan hanya ilmu pengetahuan tetapi juga kegiatan profesional yang dilaksanakan oleh supervisor (kepala sekolah dan pengawas sekolah) melalui pengawasan, pembinaan, dan layanan bantuan kepada para guru untuk pengembangan kinerja guru di sekolah.

Arikunto mengemukakan tiga sasaran supervisi pendidikan, yaitu pembelajaran, pendukung kelancaran pembelajaran atau administrasi guru dan kelembagaan. ${ }^{25}$ Suhardan mengelompokkan supervisi pendidikan kedalam 3 jenis, yaitu: (1) supervisi akademik yang dititikberatkan pada hal-hal yang terjadi dalam kegiatan pembelajaran; (2) supervisi administrasi yang dititikberatkan pada aspek-aspek pendukung dan pelancar terlaksananya pembelajaran; dan (3) supervisi lembaga yang dititikberatkan pada aspekaspek sekolah untuk meningkatkan kinerja sekolah secara keseluruhan. ${ }^{26}$ Berdasarkan uraian di atas, dapat disimpulkan bahwa sasaran supervisi pendidikan adalah pengkajian situasi pembelajaran, peningkatan situasi pembelajaran, dan penilaian terhadap media, metode, dan hasil pembelajaran. Sasaran supervisi pendidikan adalah meningkatkan mutu proses dan hasil pembelajaran melalui layanan pengawasan, pembinaan, dan bantuan kepada para guru untuk pengembangan kinerja guru di sekolah.

Model Supervisi Pengembangan adalah model supervisi yang dikembangkan oleh Glickman, Gordon dan Ross-Gordon. Supervisi pengembangan, meliputi: pengembangan kurikulum, observasi, dan pengembangan profesionalisme guru. Pengembangan kurikulum, yaitu bimbingan dan bantuan yang diberikan oleh supervisor kepada guru dalam proses merancang, menyelaras, dan melaksanakan kurikulum di sekolah. Pengembangan kurikulum melibatkan aktivitas-aktivitas yang melibatkan supervisor dan guru untuk meningkatkan keberhasilan pelaksanaan kurikulum di sekolah. Observasi merupakan supervisi pembelajaran yang memerlukan supervisor masuk ke dalam kelas ketika guru sedang melaksanakan kegiatan pembelajaran. Pengembangan profesionalisme guru dilakukan dengan memberi kesempatan dan dorongan kepada para guru untuk meningkatkan profesionalitas mereka dalam merencanakan dan melaksanakan pembelajaran, serta melaksanakan evaluasi pembelajaran. Kerangka teori supevisi pengembangan Glickman dkk. dapat dilihat pada Gambar 1 berikut ini: 
Gambar 1 Kerangka Teori Supervisi Pengembangan Glickman dkk.

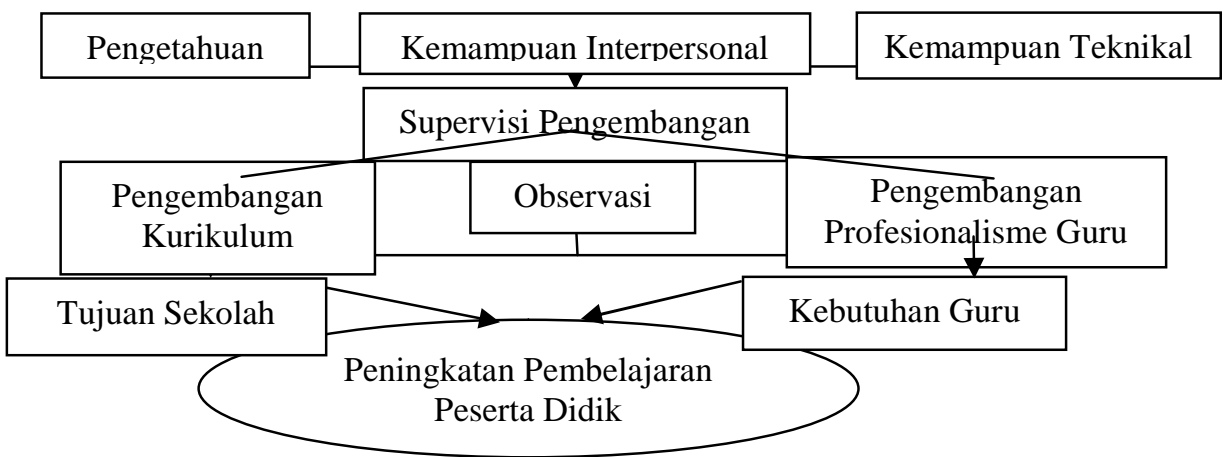

Model Supervisi Rekan Sejawat/Peer Supervision adalah model supervisi yang dilakukan oleh rekan sejawat untuk saling membantu satu sama lain. Supervisi ini tidak bersifat menilai tetapi mengutamakan kerjasama dalam menemukan perbaikan pembelajaran berdasarkan hasil observasi rekan sejawat. Model ini mempunyai kesamaan dengan kegiatan pemberdayaan guru melalui pengembangan kinerja guru secara berkelanjutan di MGMP. Pemberdayaan guru melalui pengembangan komunitas belajar profesional dilaksanakan dalam bentuk penerapan lesson study. Mulyana mengemukakan, sebagaimana dikutip Rusman, bahwa lesson study adalah suatu model pembinaan profesi pendidik melalui pengkajian pembelajaran secara kolaboratif dan berkelanjutan berlandaskan prinsip-prinsip kolegalitas dan mutual learning untuk membangun learning community. Tujuan lesson study adalah untuk: (1) memperoleh pemahaman yang lebih baik tentang bagaimana siswa belajar dan guru mengajar; (2) memperoleh hasil-hasil tertentu yang bermanfaat bagi guru lainnya dalam melaksanakan pembelajaran; (3) meningkatkan pembelajaran secara sistematis melalui inquiry kolaboratif; (4) membangun sebuah pengetahuan pedagogis dari guru kepada guru lainnya. ${ }^{28}$ Lesson study sebenarnya dapat dijadikan satu model pengembangan kinerja guru baik di tingkat sekolah maupun di tingkat kabupaten/kota. Melalui model ini para guru dapat melakukan pengkajian pembelajaran secara kolaboratif dan berkelanjutan berlandaskan prinsipprinsip kolegalitas dan mutual learning untuk membangun learning community dengan melibatkan pakar dari Lembaga Pendidikan Tenaga Kependidikan (LPTK) atau perguruan tinggi terdekat.

Model Supervisi Inkuiri/Action Researh merupakan pendekatan yang merujuk kepada kajian yang dilakukan sendiri oleh guru melalui refleksi terhadap pembelajaran. 
Melalui supervisi inkuiri, guru secara individu atau dengan kerjasama dengan guru-guru lain melibatkan diri dalam penelitian tindakan kelas untuk memperbaiki mutu pembelajaran. Pengembangan kinerja guru, disamping melalui supervisi pendidikan, dapat pula melalui pemberdayaan guru dapat pula dilakukan dengan memberi kesempatan dan fasilitas kepada guru untuk melaksanakan Penelitian Tindakan Kelas (PTK). PTK merupakan suatu pencermatan terhadap kegiatan belajar berupa sebuah tindakan yang sengaja dimunculkan dan terjadi dalam sebuah kelas secara bersama. PTK adalah kegiatan ilmiah sehingga laporan hasil PTK merupakan Karya Tulis IImiah (KTI) yang menjadi salah satu aspek pengembangan profesi guru.

Model Supervisi Klinik diperkenalkan oleh Cogan dan dikembangkan oleh Goldhammer dkk. R. Willem menyebut supervisi klinik sebagai model supervisi yang difokuskan pada masalah ril yang dialami guru. Model ini memberi peluang kepada guru untuk berinisiatif menemukan masalahnya dalam pembelajaran dan berusaha mencari alternatif pemecahannya melalui siklus ysng sistematis, perencanaan, pengamatan, dan analisis yang intensif serta cermat terhadap penampilan (kinerja) mengajar guru. Supervisi klinik membantu guru memperkecil kesenjangan antara tingkah laku mengajar yang nyaya dengan tingkah laku mengajar yang ideal. Model ini terpusat pada perbaikan penampilan dan perilaku mengajar guru.

Teknik supervisi pendidikan adalah cara sistematis yang digunakan dalam melaksanakan program supervisi pendidikan secara kelompok atau individu, baik langsung (bertatap muka), maupun tidak langsung (melalui media komunikasi). Pandangan ini sejalan dengan pendapat Anderson dan Gall yang mengelompokkan teknik supervisi berdasarkan banyaknya guru yang dibimbing, yaitu teknik kelompok dan teknik individual. Rifai membedakan teknik supervisi berdasarkan cara melakukan supervisi, yaitu supervisi langsung dan supervisi tidak langsung. Engkoswara dan Aan Komariah mengemukakan tujuh teknik supervisi, yaitu: (1) Kunjungan sekolah/school visit; (2) Kunjungan kelas/class visit, (3) Kunjungan antar sekolah/intervisitation; (4) Pertemuan Pribadi/Individual Conference;(5) Rapat Guru; (6) Penerbitan bulletin profesional; dan (7) Penataran. Hal senada dikemukakan oleh Hilal Mahmud dengan beberapa tambahan, yaitu: (1) Kelompok Diskusi Terfokus/Focus Group Discussion; (2) Penelitian Tindakan Kelas/ Classroom Action Research; (3) Portofolio/ Portfolio; 
(4) Kerjasama/Network; (5) Mentoring; (6) Lesson Study. ${ }^{29}$ Berdasarkan uraian di atas, dapat disimpulkan bahwa dalam upaya memberikan layanan pengawasan, pembinaan, dan bantuan kepada guru uintuk mengembangkan kinerjanya, berbagai teknik supervisi dapat digunakan oleh supervisor untuk membantu para guru meningkatkan penampilan dan hasil kerja (kinerja) mereka, baik secara kelompok atau individu maupun secara langsung atau tidak langsung.

Kebutuhan guru akan dorongan motivasi dan suasana kondusif untuk mewujudkan pemberdayaan guru membutuhkan kepemimpinan kepala sekolah yang memiliki kemampuan mengembangkan setiap guru menjadi self-leader. Guru yang self leader adalah guru yang memiliki pola pikir, perilaku dan tanggungjawab mengatasi tantangan yang dibebankan kepadanya, inisiatif, kreatif, inovatif, dan mampu memimpin diri mereka sendiri. Kepala sekolah yang mampu mendesain, menetapkan sistem, memengaruhi, dan membentuk guru menjadi self-leader adalah superleader. Superleader adalah pemimpin yang mampu memimpin orang lain untuk memimpin diri sendiri. Superleader memungkinkan esensi semua kontrol atas kinerja guru adalah pada kompetensi dan potensi guru itu sendiri. ${ }^{31}$ Kepala sekolah yang superleader memungkinkan memiliki kemampuan mendorong SDM guru untuk berinisiatif, bertanggungjawab sendiri, percaya diri, merencanakan tujuan sendiri, berpikir secara positif, dan mampu mengatasi permasalahan. Kepala sekolah yang superleader memberi semangat kepada guru untuk bertanggungjawab, fokus pada strategi pemberdayaan melalui peningkatan keterampilan, pengetahuan, dan keyakinan akan kemampuan dan potensi guru yang dipimpinnya.

\section{METODE PENELITIAN}

Penelitian ini termasuk jenis penelitian lapangan yang kajiannya bersifat kualitatif-verifikatif untuk mengungkap makna yang ada di balik fenomena realitas sosial tentang pelaksanaan model pengembangan kinerja guru pada SMA Negeri di Kota Palopo. Strategi analisis data dalam penelitian ini mengarah pada strategi analisis data kualitatifverifikatif yaitu berupaya menganalisis data penelitian secara induktif yang dilakukan pada seluruh proses penelitian yang dilakukan. Penelitian ini juga tidak menetapkan penelitiannya berdasarkan variabel penelitian tetapi keseluruhan situasi sosial yang diteliti 
meliputi aspek tempat (place), yaitu SMA Negeri di Kota Palopo, pelaku (actor), yaitu para Kepala Sekolah, Pengawas Sekolah dan guru SMA Negeri di Kota Palopo, Komite Sekolah, serta Dewan Pendidikan Kota Palopo, dan aktivitas (activity), yaitu pelaksanaan model pengembangan kinerja guru, melalui supervisi pendidikan dan pemberdayaan guru (individu maupun organisasi) pada SMA Negeri di Kota Palopo. Pendekatan yang digunakan dalam penelitian ini adalah pendekatan fenomenologi dalam upaya memahami makna dari suatu peristiwa atau fenomena yang saling berpengaruh dengan pelaku dalam situasi tertentu dalam pelaksanaan model pengembangan kinerja guru pada SMA Negeri di Kota Palaopo.

Dalam penelitian ini peran peneliti adalah sebagai instrumen kunci dalam mengumpulkan data dengan menggunakan pengamatan langsung, wawancara, dan studi dokumen terhadap pelaksanaan model pengembangan kinerja guru pada SMA Negeri di Kota Palopo. Pengamatan langsung dilakukan dengan cara mengamati guru, berusaha masuk di dalam dunia konseptual mereka dan berinteraksi dengan mereka di sekolah agar dapat memahami konstruksi berpikir mereka tentang pelaksanaan model pengembangan kinerja guru yang mereka alami. Wawancara dilakukan dengan berusaha memahami, menggali pandangan dan pengalaman mereka untuk mendapatkan informasi atau data yang diperlukan. Data yang dikumpulkan dalam penelitian ini berupa data primer dan data sekunder. Instrumen utamanya adalah peneliti sendiri untuk menetapkan fokus penelitian, memilih informan sebagai sumber data, melakukan pengumpulan data, menilai kualitas data, analisis data, menafsirkan data dan membuat kesimpulan atas temuannya. Instrumen pendukung adalah pedoman wawancara, pedoman observasi dan field note (catatan lapangan).

Penelitian ini merupakan kajian sosiologis mikro dengan mengamati model pengembangan kinerja guru pada SMA Negeri di Kota Palopo. Data yang terkumpul dianalisis secara kualitatif dengan menggunakan pendekatan logika induktif, dimana silogisme dibangun berdasarkan pada hal-hal khusus atau data di lapangan dan bermuara pada kesimpulan-kesimpulan umum. Strategi analisis data seperti dikemukakan di atas digunakan untuk memahami, mengkaji, dan menganalisis pelaksanaan model pengembangan kinerja guru pada SMA Negeri di Kota Palopo. Proses pengelolaan dan 
analisis data dalam penelitian ini dilakukan sejak sebelum memasuki lapangan, selama di lapangan, dan setelah selesai di lapangan.

\section{HASIL PENELITIAN DAN PEMBAHASAN}

\section{Model Pengembangan Kinerja Guru pada SMA Negeri di Kota Palopo}

Berdasarkan data dari hasil observasi, wawancara, dan studi dokumentasi, peneliti menemukan bahwa model pengembangan kinerja guru yang diterapkan pada SMA Negeri di Kota Palopo adalah model pengembangan kinerja guru melalui supervisi pendidikan. Model pengembangan kinerja guru melalui pemberdayaan guru (PTK dan MGMP) belum dijadikan program pengembangan kinerja guru pada SMA Negeri di Kota Palopo. Penelitian Tindakan Kelas (PTK) hanya dilaksanakan oleh sebagian guru untuk memenuhi persyaratan kenaikan pangkat dari Golongan IV/a menjadi IV/b. Musyawarah Guru Mata Pelajaran juga belum sepenuhnya dimanfaatkan oleh para guru sebagai wadah berbagi pengalaman dan mendiskusikan cara pemecahan masalah pembelajaran yang dialami di dalam kelas.

Model pengembangan kinerja guru melalui supervisi pendidikan merupakan proses interaksi yang teratur dan sistematis antara supervisor (pengawas sekolah/kepala sekolah/guru senior) melalui tahapan sebagai berikut: (1) tahap pra observasi, dilaksanakan sebelum supervisor mengunjungi kelas sasaran. Pada tahap ini supervisor mensupervisi administrasi guru untuk memastikan kesiapan guru dalam mengajar; (2) tahap pelaksanaan observasi di dalam kelas sasaran, memantau penampilan kerja guru dalam kelas dan mencatat temuan/kinerja guru dalam pembelajaran; dan (3) tahap post-observasi/refleksi, dilaksanakan setelah pelaksanaan observasi di dalam kelas. Tahap post-observasi/refleksi adalah tahap pembinaan, pendampingan dan pengembangan penampilan kerja guru dengan merefleksikan seluruh aktivitas dan mendiskusikan berbagai temuan dalam pelaksanaan observasi. Model pengembangan kinerja guru pada SMA Negeri di Kota Palopo dapat digambarkan sebagai berikut: 
Gambar 2 Model Pengembangan Kinerja Guru pada SMA Negeri di Kota Palopo

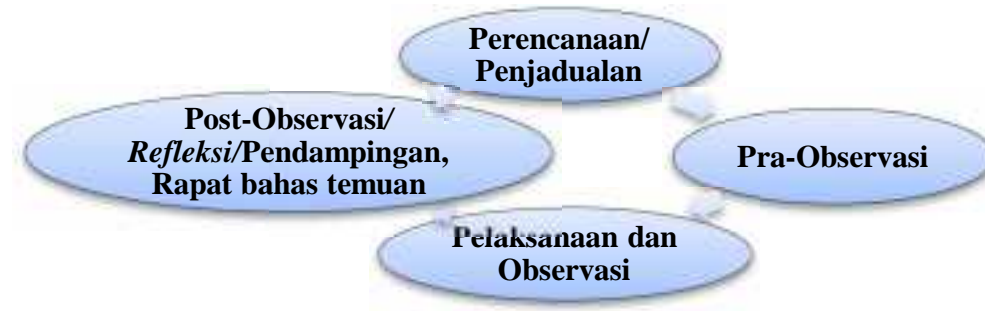

Model pengembangan kinerja guru pada SMA Negeri di Kota Palopo sebagaimana digambarkan di atas memiliki kesamaan dengan model manajemen kinerja Deming dengan beberapa terminologi berbeda. Untuk memudahkan membandingkan model pengembangan kinerja guru pada SMA Negeri di Kota Palopo dan manajemen kinerja Deming, peneliti menggambarkan model manajemen kinerja Deming, sebagai berikut:

Gambar 3 Model (Siklus) Manajemen Kinerja Deming

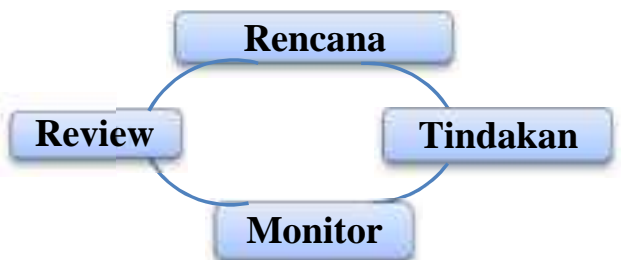

Model manajemen kinerja Deming dimulai dengan menyusun rencana sedangkan model pengembangan kinerja guru pada SMA Negeri di Kota Palopo juga dimulai dengan rencana namun hanya sebatas menyusun jadual. Dalam pelaksanaannya, jadual yang dibuat kadang-kadang diabaikan dan hanya mengikuti jadual tugas mengajar guru yang akan disupervisi. Siklus kedua (tindakan, yaitu melakukan tindakan pelaksanaan,) dan ketiga (monitor, yaitu mengamati jalannya kegiatan dan hasil ) dari model manajemen kinerja Deming, memiliki kesamaan dengan tahap pra-observasi (memeriksa kesiapan guru dalam menghadapi kegiatan pembelajaran di dalam kelas) dan pelaksanaan observasi (mengamati pelaksanaan kegiatan pembelajaran) pada model pengembangan kinerja guru pada SMA Negeri di Kota Palopo. Siklus keempat (review, yaitu melakukan peninjauan kembali atas jalannya pelaksanaan dan kemajuan pekerjaan yang telah dicapai serta melakukan tindakan perbaikan untuk memastikan pencapaian tujuan) memiliki kesamaan dengan tahap post-observasi atau refleksi (melakukan pembinaan, pendampingan dan pengembangan penampilan kerja guru dengan 
merefleksikan seluruh aktivitas dan mendiskusikan berbagai temuan dalam pelaksanaan observasi) dan tahap rapat guru (melakukan pembinaan dan pendampingan untuk semua guru) pada model pengembangan kinerja guru pada SMA Negeri di Kota Palopo.

Berdasarkan data dari hasil observasi, wawancara, dan studi dokumentasi, peneliti menemukan bahwa model pengembangan kinerja guru pada SMA Negeri di Kota Palopo belum berjalan optomal. Dalam praktiknya, ditemukan beberapa kelemahan pada tahap perencanaan, pelaksanaan, monitor, dan review dengan merujuk pada model manajemen kinerja Deming. Pada tahap perencanaan dalam model pengembangan kinerja guru pada SMA Negeri di Kota Palopo baru sebatas penjadualan kegiatan, belum dibuat khusus dan detail berdasarkan analisa kebutuhan. Demikian halnya pada tahap selanjutnya masih terdapat sejumlah kelemahan. Pemberian bantuan, bimbingan, dan pendampingan kepada guru masih kurang optimal karena alasan keterbatasan waktu yang tersedia. Rapat guru membahas temuan juga kurang optimal karena waktu yang digunakan singkat serta pembahasannya sangat umum dan tidak detail. Dalam rangka memperbaiki kelemahan yang terjadi pada model pengembangan kinerja guru pada SMA Negeri di Kota Palopo maka beberapa aktivitas dalam model manajemen kinerja Torrington dan Hall serta model manajemen kinerja Ken Blanchard dan Garry Ridge penting dipertimbangkan. Model manajemen kinerja Torrington dan Hall serta model manajemen kinerja Ken Blanchard dan Garry Ridge dapat digambarkan sebagai berikut:

Gambar 4 Model Manajemen Kinerja Torrington dan Hall

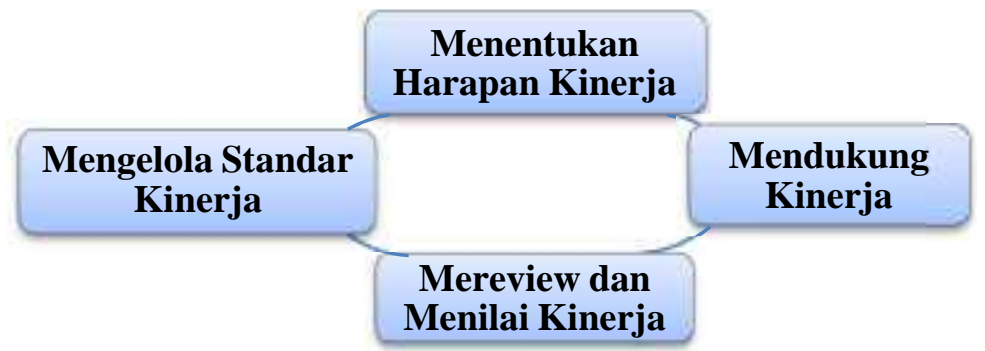

Gambar 5 Model (Sistem) Manajemen Kinerja Ken Blanchard dan Garry Ridge 


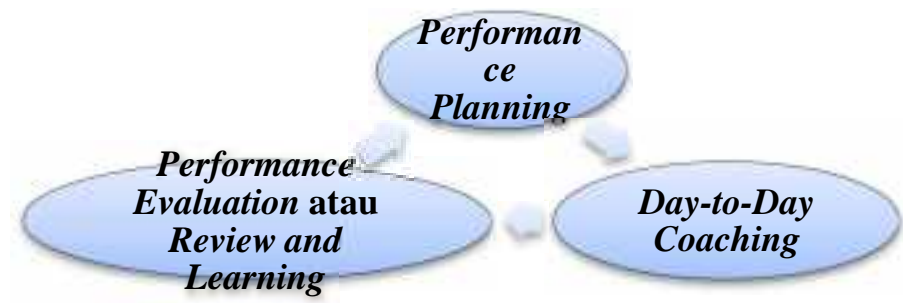

Kelemahan dalam perecanaan pada model pengembangan kinerja guru pada SMA Negeri di Kota Palopo perlu diperbaiki dengan melakukan tindakan menetapkan tujuan, sasaran, dan standar kerja sebagaimana tahapan perencanaan kinerja (performance planning) dari Blanchard dan Ridge atau merumuskan dan menentukan harapan kinerja serta memastikan adanya dukungan (fasilitas, dana, tindakan yang menginspirasi) sebagaimana tahapan model manajemen kinerja Torrington dan Hall. Tahapan evaluasi kinerja (performance evaluation) atau peninjauan ulang dan pembelajaran (review and learning) dari model manajemen kinerja Blanchard dan Ridge perlu pula dipertegas bentuk pelaksanaannya dalam model pengembangan kinerja guru pada SMA Negeri di Kota Palopo. Tahapan evaluasi kinerja sebaiknya dilakukan dalam pertemuan yang dihadiri para guru, pengawas sekolah, dan didampingi pakar dari perguruan tinggi mitra sekolah. Tahapan ini akan lebih bermakna bagi pengembangan kinerja guru jika dilaksanakan atas inisiatif guru (pemberdayaan) dan didukung sepenuhnya (fasilitas, dana, dan tindakan menginspirasi) oleh kepemimpinan kepala sekolah.

Tindakan peninjauan ulang dan pembelajaran dapat dilakukan oleh kelompok guru mata pelajaran sejenis dalam bentuk Focused Group Discussion atau mengadopsi nilai kearifan lokal dalam bentuk "Tudang Sipulung", yaitu melakukan pengkajian pembelajaran secara kolaboratif dan berkelanjutan berlandaskan prinsip-prinsip kolegalitas untuk membangun komunitas belajar (learning community). Komunitas belajar ini berupaya memperoleh: (1) pemahaman yang lebih baik tentang bagaimana peserta didik belajar dan guru mengajar; (2) model-model pembelajaran inovatif yang dilakukan oleh guru lain dalam pembelajaran; (3) mengembangkan kompetensi guru (pedagogis, personal, sosial dan profesional) dari guru kepada guru lainnya. 


\section{Pelaksanaan Model Pengembangan Kinerja Guru Melalui Supervisi Pendidikan pada SMA Negeri di Kota Palopo}

Berdasarkan hasil penelitian yang dikemukakan pada bagian sebelumnya, ditemukan bahwa pelaksanaan model pengembangan kinerja guru melalui supervisi pendidikan, meliputi supervisi administrasi guru dan supervisi kunjungan kelas. Supervisi administrasi guru pada umumnya dilaksanakan segera sebelum supervisi kunjungan kelas, namun dapat pula dilaksanakan di awal semester setelah para guru menyusun perangkat administrasi guru dalam kelompok guru mata pelajaran di bawah koordinasi Tim Pengembang Kurikulum. Jika supervisi administrasi guru dilaksanakan segera sebelum supervisi kunjungan kelas maka aktivitas itu menjadi bagian dari prosedur atau tahapan supervisi kunjungan kelas, yaitu pra-observasi. Prosedur atau tahapan supervisi kunjungan kelas, meliputi pra-observasi, observasi, dan refleksi. Tahap pra observasi dilakukan untuk membantu guru mempersiapkan diri melaksanakan kegiatan pembelajaran di kelas. Pada tahap ini guru harus memperlihatkan silabus dan RPP kepada supervisor. RPP penting dibawa masuk kelas karena dijadikan pedoman dalam pembelajaran. Pada tahap observasi, supervisor mencatat berbagai temuan dengan menggunakan format supervisi pembelajaran yang sudah disiapkan. Pada tahap refleksi, supervisor menyampaikan beberapa temuan dalam kegiatan pembelajaran dan berusaha mendiskusikan masalahmasalah yang jadi temuan tersebut untuk perbaikan kinerja guru bersangkutan. Jika salah satu atau beberapa temuan dalam kegiatan pembelajaran merupakan masalah umum guru, maka hal itu menjadi catatan supervisor untuk dibawa ke forum pertemuan guru untuk didiskusikan.

Ada sejumlah alasan mengapa kehadiran pengawas sekolah atau kepala sekolah dalam supervisi kunjungan kelas sering memengaruhi penampilan guru dalam pembelajaran. Kehadiran supervisor lebih dominan mengawasi dan menilai penampilan kerja guru yang dalam paradigma lama sebagai alat kontrol birokrasi untuk mengetahui keterlaksanaan program-programnya. Hal ini didukung oleh fakta bahwa temuan supervisor berkaitan dengan ada tidaknya perangkat administrasi guru, pelaksanaan pembelajaran tidak sesuai dengan yang tertera dalam RPP, dan pelaksanaan pembelajaran tidak sesuai alokasi waktu. Beberapa temuan supervisor dapat dijadikan bahan perbaikan pembelajaran, misalnya: kelemahan dalam membuka dan menutup 
pembelajaran, kelemahan dalam penggunaan model/strategi/metode pembelajaran, dan kelemahan dalam pemanfaatan media pembelajaran berbasis IT. Temuan-temuan tersebut ditindaklanjuti dengan pertemuan pribadi antara supervisor dan guru, hasil temuan disampaikan di dalam rapat guru, dan atau disampaikan kepada kepala sekolah sebagai bahan penilaian kinerja guru.

Berdasarkan hasil wawancara dan observasi, peneliti menemukan bahwa pelaksanaan pengembangan kinerja guru melalui supervisi pendidikan pada SMA Negeri di kota Palopo belum memberikan ruang yang cukup bagi guru untuk berpartisipasi. Kondisi ini menafikan paradigma bahwa guru sebagai tenaga pendidik profesional memiliki otonomi dalam membuat keputusan penting dalam pembelajaran. Padahal, supervisi pendidikan seyogyanya memberi ruang yang cukup bagi pemberdayaan guru. Pemberdayaan berarti memberi ruang yang cukup bagi guru untuk berpartisipasi dalam mengembangkan kinerjanya melalui berbagai aktivitas yang dirancang dari awal oleh sekolah. Pada sisi ini, temuan dalam penelitian ini menguatkan hasil penelitian Atip Suherman dengan judul "Kontribusi Implementasi Manajemen Partisipatif Terhadap Kinerja Guru dan Terhadap Kegiatan Belajar Mengajar di SMA Negeri 4 Bogor" yang menyimpulkan bahwa manajemen partisipatif yang dilaksanakan di SMA Negeri 4 Kota Bogor telah memberikan kontribusi yang cukup signifikan terhadap pengembangan kinerja guru dan kegiatan belajar mengajar berlangsung lebih efektif.

Temuan-temuan dalam supervisi pendidikan, seyogyanya, ditindaklanjuti dengan program pembinaan yang lebih memberdayakan, misalnya pemberian dukungan yang kuat baik dana maupun bimbingan teknis yang intens sehingga memotivasi dan membangkitkan komitmen guru dalam kegiatan PTK dan MGMP untuk mewujudkan pembelajaran inovatif. Pada sisi ini, kajian Uhar Suharsaputra tentang model pengembangan kinerja guru melalui dua pendekatan patut dipertimbangkan oleh supervisor. Pendekatan individu yang dilakukan oleh supervisor (kepala sekolah dan pengawas sekolah) diamati melalui kegiatan supervisi administrasi, supervisi kunjungan kelas, serta pemberdayaan guru melalui penelitian tindakan kelas. Pendekatan organisasi dan manajemen yang dilakukan oleh supervisor (kepala sekolah dan pengawas sekolah) diamati melalui kegiatan pemberdayaan guru melalui organisasi Musyawarah Guru Mata Pelajaran (MGMP). 
Pelaksanaan model pengembangan kinerja guru melalui supervisi pendidikan, khususnya supervisi kunjungan kelas belum optimal dan mengalami hambatan di beberapa sekolah. Keterbatasan waktu adalah alasan yang pada umumnya dikemukakan oleh kepala sekolah. Selain itu, faktor terbatasnya fasilitas sekolah, terbatasnya biaya, sikap guru yang sulit berubah merupakan kendala yang dilihat oleh beberapa pengawas sekolah. Hambatan lain dalam pelaksanaan supervisi pendidikan, khususnya supervisi kunjungan kelas, dikemukakan oleh beberapa kepala sekolah pada SMA Negeri di Kota Palopo, yaitu ketidaksiapan sebahagian guru untuk berubah, persepsi guru tentang supervisi, dan keterbatasan dana untuk melaksanakan tindak lanjut temuan berupa diklat, penelitian tindakan kelas atau pertemuan guru di MGMP. Hambatan-hambatan yang dikemukakan di atas berdampak pada suasana dan iklim kerja yang tidak kondusif di sekolah.

Faktor iklim kerja ini perlu disikapi dengan memahami teori lingkungan Taiguri yang mengemukakan bahwa aspek fisik (ekologi) dan cara berpikir anggota organisasi sebagai bagian dari budaya kerja membentuk iklim kerja di sekolah. Taiguri mengemukakan bahwa iklim yang terdapat dalam sutu organisasi, termasuk sekolah, terdiri dari ekologi (aspek fisik, teknologi, kemudahan dll), miliu (dimensi sosial: etnis, gaji, pendidikan, kepuasan), sistem sosial dalam organisasi (struktur administrasi, komunikasi, dII), dan budaya sekolah (nilai, sistem kepercayaan, dan cara berpikir). Keterbatasan waktu, dana dan fasilitas sekolah yang menunjang pembelajaran memengaruhi cara berpikir mereka untuk tidak melakukan perubahan. Kemudahan dalam mengakses dan menguasai pemanfaatan teknologi informasi juga merupakan kendala para pendidik pada SMA Negeri di Kota Palopo yang memengaruhi iklim kerja yang kondusif mengembangkan kinerja mereka. Faktor komunikasi yang dilakukan oleh supervisor dan para guru agaknya kurang memadai untuk membangun iklim kerja yang kondusif dalam mengembangkan kinerja guru di sekolah. Hal tersebut terjadi karena jadual mengajar padat dan beban kerja (jumlah jam pelajaran yang diampuh) guru rata-rata melebihi jam wajib guru.

Sikap sebahagian pendidik pada SMA Negeri di Kota Palopo yang sulit berubah merupakan perlawanan terhadap perubahan. Ada sejumlah faktor penyebab pendidik melawan adanya perubahan, yaitu: keamanan, interaksi sosial, status, kompetensi, dan kepercayaan dirinya terancam. Dalam kasus guru pada SMA Negeri di Kota Palopo, 
penyebab sebagian guru sulit berubah adalah faktor kompetensi. Hal tersebut terlihat pada hasil temuan supervisor dalam kegiatan pembelajaran yang menunjukkan kelemahan sebagian guru dalam memanfaatkan teknologi informasi serta kurangnya kreativitas untuk menciptakan inovasi model pembelajaran. Hasil penilaian kinerja guru oleh supervisor juga menunjukkan bahwa dalam pelaksanaan pembelajaran sebagian guru lemah dalam mendorong keterlibatan peserta didik dalam pembelajaran. Demikian pula pengorganisasian waktu, ruang, bahan, dan perlengkapan pembelajaran masih menunjukkan kinerja guru lemah. Kinerja guru dalam hubungan antar pribadi juga menunjukkan sebagian guru masih lemah dalam mengelola interaksi perilaku dalam pembelajaran.

Untuk mengatasi hambatan dalam pelaksanaan model pengembangan kinerja guru dibutuhkan kepemimpinan kepala sekolah yang mampu mengatur dan mengelola waktu serta mampu memengaruhi cara berpikir para guru yang dipimpinnya untuk menjadi bagian dari sekolah pembelajar, yaitu sekolah dimana para warganya senantiasa memiliki motivasi kuat untuk belajar dan berubah ke arah yang lebih baik. Pengaruh kepemimpinan dalam meningkatkan motivasi dan kinerja guru cukup signififan sebagaimana hasil penelitian Rustan S. dengan judul "Pengaruh Kepemimpinan Kepala Madrasah Aliyah terhadap Motivasi Kerja dan Kinerja Guru Bahasa Inggeris di Sulawesi Selatan". Penelitian Rustan menunjukkan bahwa gaya dan situasi kepemimpinan Kepala Madrasah Aliyah serta iklim organisasi Madrasah Aliyah di Sulawesi Selatan secara simultan berpengaruh positif dan signifikan baik terhadap motivasi kerja maupun terhadap kinerja guru bahasa Inggeris. Demikian pula penelitian Hilal Mahmud dengan judul "Pengaruh Kepemimpinan dan Motivasi Kepala Sekolah terhadap Prestasi Kerja Guru SMA Negeri di Kabupaten Luwu Utara" yang menunjukkan bahwa terdapat pengaruh positif kepemimpinan dan motivasi kepala sekolah secara bersama-sama terhadap prestasi kerja guru SMA Negeri di Kabupaten Luwu Utara.

Dalam upaya mengatasi hambatan dalam pelaksanaan model pengembangan kinerja guru pada SMA Negeri di Kota Palopo diperlukan peningkatan kualitas kepemimpinan kepala sekolah. Upaya mengembangkan kinerja guru tidak dapat diwujudkan tanpa disertai usaha meningkatkan kualitas kepemimpinan kepala sekolah. Peningkatan kualitas kepemimpinan berarti peningkatan kemampuan, kualifikasi, dan 
kompetensi kepala sekolah dalam memimpin sekolah. Usaha meningkatkan kualitas kepemimpinan harus dilakukan secara terus menerus dan berkesinambungan, mengingat kondisi kehidupan sekolah sangat dinamis. Untuk itu perlu dipertimbangkan ulang untuk mempersiapkan calon kepala sekolah secara berjenjang melalui uji kompetensi kepala sekolah dan workshop calon kepala sekolah sebelum pada akhirnya dipilih dan diangkat sebagai kepala sekolah.

Kepala sekolah yang telah melalui uji kompetensi dan workshop tetap senantiasa meningkatkan kualitas kepemimpinannya secara mandiri. Veithzal Rivai dan Deddy Mulyadi menawarkan empat cara yang dapat dilakukan oleh pemimpin untuk meningkatkan kualitas kepemimpinannya, yaitu: (1) berpikir efektif dalam menerapkan keputusan; (2) mengkomunikasikan hasil berpikir; (3) meningkatkan partisipasi dalam memecahkan masalah; dan (4) menggali dan meningkatkan kreativitas. Berpikir efektif berarti kepala sekolah senatiasa berpikir kritis, rasional, objektif, tidak boleh dilakukan secara emosional, dan terbuka dalam mempertimbangkan masukan dari para pendidik. Berpikir efektif juga berarti bahwa berpikir itu harus menghasilkan sesuatu yang sesuai dengan kebutuhan dalam kehidupan sekolah. Kepala sekolah harus mampu memilih alternatif keputusan yang tepat berdasarkan kemampuan menganalisis kekuatan, kelemahan, peluang, dan ancaman. Kemampuan berfikir efektif merupakan potensi psikis yang sangat istimewa dan patut senantiasa diasah oleh kepala sekolah. Dengan demikian, berfikir efektif menghasilkan suatu komitmen pribadi yang memungkinkan seseorang melakukan atau tidak melakukan suatu keputusan. Komitmen harus bisa diterjemahkan menjadi gagasan, prakarsa, inisiatif, kreativitas, pendapat, saran, dan perintah melalui keterampilan komunikasi kepala sekolah. Keputusan didasarkan pada komitmen ditunjukkan Allah swt. sebagaimana firman-Nya dalam QS. Qa>f/50: 29, sebagai berikut:

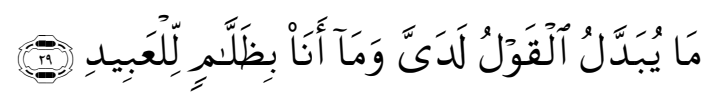

Terjemahnya:

Keputusan-Ku tidak dapat diubah, dan Aku tidak menzalimi hamba-hamba-Ku. ${ }^{32}$

Keputusan kepala sekolah yang didasarkan pada komitmen diharapkan dapat meningkatkan partisipasi pendidik dalam memecahkan masalah-masalah pembelajaran 
mereka. Kemampuan kepala sekolah mewujudkan partisipasi dalam memecahkan masalah secara bersama-sama akan melahirkan rasa tanggung jawab dan kreativitas pendidik menemukan model-model pembelajaran inovatif. Kepala sekolah harus senantiasa menggali dan memanfaatkan potensi kreativitas para pendidik dengan cara terus menerus mendorong para pendidik mengembangkan potensi kreativitas yang dimilikinya. Veithzal Rivai dan Deddy Mulyadi dalam Kepemimpinan dan Perilaku Organisasi menjelaskan bahwa kreativitas berarti memiliki daya cipta, memiliki kemampuan untuk mencipta, bersifat daya cipta. Allah swt. memerintahkan hamba-Nya untuk tidak tidak melakukan sesuatu urusan jika tidak memiliki pengetahuan tentang hal tersebut, sebagaimana firman-Nya dalam QS. Al-Isra>/17:36, sebagai berikut:

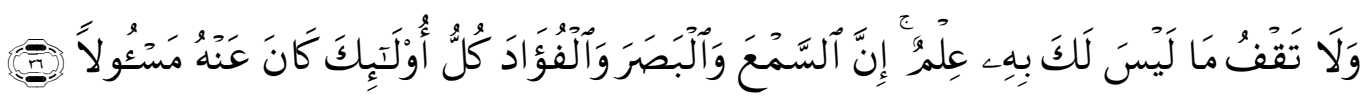

Terjemahnya:

Dan janganlah kamu mengikuti sesuatu yang tidak kamu ketahui. Karena pendengaran, penglihatan, dan hati nurani, semua itu akan diminta pertanggungjawabannya. ${ }^{33}$

\section{Pelaksanaan Model Pengembangan Kinerja Guru Melalui Pemberdayaan pada SMA Negeri di Kota Palopo}

Berdasarkan hasil penelitian yang dikemukakan pada bagian sebelumnya, ditemukan data bahwa pelaksanaan model pengembangan kinerja guru melalui pemberdayaan, meliputi Penelitian Tindakan Kelas (PTK) dan Musyawarah Guru Mata Pelajaran (MGMP). Berdasarkan hasil wawancara, peneliti menemukan data bahwa pelaksanaan pengembangan kinerja guru melalui pemberdayaan, khususnya PTK pada SMA Negeri di Kota Palopo belum optimal. Pelaksanaan PTK pada SMA Negeri di Kota Palopo sebagai wahana pemecahan masalah pembelajaran dan pencarian model pembelajaran inovatif belum dimanfaatkan sebaik-baiknya oleh pihak sekolah. Sebahagian besar guru melaksanakan PTK hanya sekedar untuk memenuhi salah satu persyaratan kenaikan pangkat dan tidak terdokumentasi dengan baik. Kendala yang mereka hadapi adalah keterbatasan waktu, dana, sumber referensi kurang, lingkungan tidak kondusif, dan 
motivasi kurang. Selain itu, sebagian guru juga masih mengalami kesulitan dalam melakukan dan menyusun laporan hasil PTK.

Jika merujuk kepada teori kinerja Gibson maka kelompok variabel yang menjadi kendala pelaksanaan PTK pada SMA Negeri di Kota Palopo adalah:

(1) Variabel Individu: Sebagian besar guru pada SMA Negeri di Kota Palopo memiliki kompetensi yang masih minim dalam melakukan penelitian tindakan kelas. Hal tersebut disebabkan oleh masih minimnya pengetahuan (knowledge) dan unjuk kerja (skill) guru tentang PTK akibat minimnya sosialisasi dan workshop PTK. Sikap individu (self-concept) guru juga perlu dipertanyakan yang mempermasalahkan keterbatasan waktu dan dana. Padahal, PTK itu dapat dilaksanakan seiring pelaksanaan kegiatan pembelajaran di kelas. Dari aspek niat dasar (motives), yang mendorong guru melakukan PTK adalah untuk memenuhi salah satu persyaratan sebagai kelengkapan bahan usul kenaikan pangkat, bukan atas dorongan untuk memecahkan masalahmasalah pembelajaran atau untuk menemukan model pembelajaran inovatif;

(2) Variabel Psikologis: Masih ada sebahagian guru yang mempersepsikan kegiatan PTK merupakan kegiatan ilmiah yang hanya tepat dilakukan oleh para peneliti dan kalangan ilmuwan. Sebahagian yang lain, biasanya yang masih muda, menganggap kegiatan PTK belum waktunya dilakukan karena belum wajib melakukan kegiatan pengembangan profesi. Yang sudah tua berpikir bahwa mereka sudah tidak memiliki kemampuan dan waktu untuk belajar, apalagi untuk melakukan kegiatan PTK;

(3) Variabel Organisasi: Sebetulnya, SMA Negeri di Kota Palopo memiliki banyak SDM guru memiliki potensi kemampuan yang dapat dikembangkan. Masalahnya, belum ada program workshop yang dirancang baik untuk mampu memotivasi guru melaksanakan PTK. Struktur organisasi sekolah dan kepemimpinan kepala sekolah juga belum memberi ruang terhadap hadirnya kreativitas dan inovasi pembelajaran. Padahal, aspek kepemimpinan kepala sekolah, desain program dan pembentukan iklim yang kondusif untuk memotivasi para guru melaksanakan kegiatan PTK perlu diwujudkan menuju sekolah kreatif dan inovatif di Era Global ini.

Pelaksanaan pengembangan kinerja guru melalui pemberdayaan Musyawarah Guru Mata Pelajaran (MGMP) belum sepenuhnya dimanfaatkan oleh para guru sebagai wadah berbagi pengalaman dan tempat pemecahan masalah pembelajaran yang dialami 
di kelas. Sebahagian besar kepala sekolah masih belum membentuk MGMP dengan pertimbangan bahwa jumlah guru mata pelajaran sejenis relatif sedikit, bahkan ada yang cuma satu orang. Dari enam SMA Negeri di kota Palopo, hanya SMA Negeri 3 Palopo yang membentuk MGMP di sekolah. Kegiatan MGMP SMA Negeri 3 Palopo terlaksana dengan baik karena kegiatan tersebut menjadi bagian penilaian kinerja sekolah sebagai sekolah rintisan bertaraf internasional. Meskipun beberapa SMA Negeri di kota Palopo tidak membentuk MGMP di sekolah, mereka membentuk Tim Pengembang Kurikulum untuk mengkoordinasikan kegiatan-kegiatan perencanaan, pelaksanaan, dan evaluasi pengembangan kurikulum di sekolah. Tugas dan fungsi Tim Pengembang Kurikulum sebahagian memiliki kesamaan dengan tugas dan fungsi MGMP, namun Tugas dan fungsi Tim Pengembang Kurikulum tidak mampu menjawab keseluruhan permasalahan pembelajaran yang menjadi temuan supervisor dalam supervisi pendidikan. Dengan demikian wadah berbagi pengalaman bagi guru dan tempat pemecahan masalah pembelajaran yang dialami di kelas, apa pun namanya, sangat dibutuhkan.

Kebutuhan akan dorongan motivasi dan suasana kondusif untuk mewujudkan pembelajaran bermutu membutuhkan kepemimpinan kepala sekolah yang superleader. Veithzal Rivai dan Deddy Mulyadi dalam Kepemimpinan dan Perilaku Organisasi mengemukakan bahwa superleader adalah pemimpin yang mampu memimpin orang lain untuk memimpin diri sendiri. Superleader memungkinkan esensi semua kontrol atas kinerja guru adalah teristimewa pada kompetensi dan potensi guru itu sendiri, mendorong SDM guru untuk berinisiatif, bertanggungjawab sendiri, percaya diri, merencanakan tujuan sendiri, berpikir secara positif, dan mampu mengatasi permasalahan. Superleader memberi semangat kepada orang lain untuk bertanggungjawab daripada memberi perintah. Superleader fokus pada strategi pemberdayaan melalui peningkatan keterampilan, pengetahuan, dan keyakinan akan kemampuan dan potensi guru yang dipimpinnya.

Kebutuhan guru akan dorongan motivasi dan suasana kondusif untuk mewujudkan pembelajaran bermutu membutuhkan kepemimpinan kepala sekolah yang memiliki kemampuan mengembangkan setiap guru menjadi self-leader. Guru yang self leader adalah guru yang memiliki pola pikir, perilaku dan tanggungjawab mengatasi tantangan yang dibebankan kepadanya, inisiatif, kreatif, inovatif, dan mampu memimpin 
diri mereka sendiri. Kepala sekolah yang mampu mendesain, menetapkan sistem, memengaruhi, dan membentuk guru menjadi self-leader adalah superleader. Mengembangkan setiap guru menjadi self-leader yang efektif adalah tantangan yang menarik dan berat. Kepala sekolah ditantang untuk mampu memimpin dan memberi motivasi kepada para guru yang dipimpinnya untuk mentransfer tanggungjawab yang dibebankan kepadanya sekaligus memimpin diri mereka sendiri dalam melaksanakan tanggungjawab itu. Kekuatan kepala sekolah sebagai Superleader dapat ditunjukkan pada kemampuannya menimbulkan komitmen pada para guru yang dipimpinnya terhadap visinya dan meyakini bahwa mereka adalah umat terbaik, sebagaimana firman Allah swt. dalam QS. Ali 'Imran/3:110, sebagai berikut:

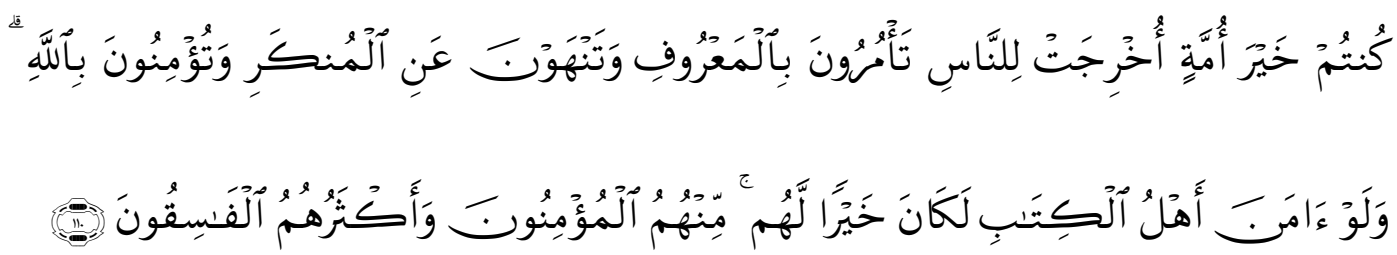

Terjemahnya:

Kamu (umat Islam) adalah umat terbaik yang dilahirkan untuk manusia, (karena kamu) menyuruh (berbuat) yang ma'ruf, dan mencegah dari yang mungkar, dan beriman kepada Allah. Sekiranya Ahli Kitab beriman, tentulah itu lebih baik bagi mereka. Di antara mereka ada yang beriman, namun kebanyakan mereka adalah orang-orang fasik. ${ }^{34}$

Untuk mendorong para guru menjadi self-leader, keteladanan Rasulullah saw. patut dijadikan inspirasi para kepala sekolah. Sifat Rasulullah yang menginspirasi ini dapat dibaca dalam QS. Al-Ah\}za>b/33:21, sebagai berikut:

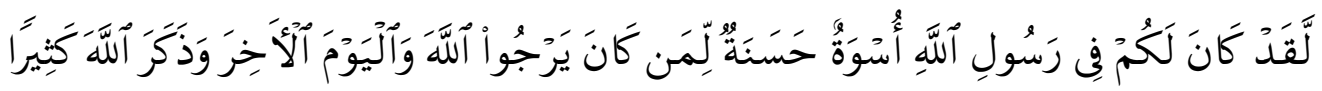

Terjemahnya:

Sesungguhnya telah ada pada (diri) Rasulullah itu suri teladan yang baik bagimu (yaitu) bagi orang yang mengharap (rahmat) Allah dan (kedatangan) hari kiamat dan dia banyak menyebut Allah. ${ }^{35}$ 


\section{E. SIMPULAN}

Berdasarkan hasil penelitian yang telah dikemukakan sebelumnya maka dapat disimpulkan hal-hal sebagai berikut:

1. Model pengembangan kinerja guru yang diterapkan di SMA Negeri di Kota Palopo adalah model pengembangan kinerja guru melalui supervisi pendidikan.

2. Pelaksanaan model pengembangan kinerja guru melalui supervisi pendidikan pada SMA Negeri di Kota Palopo belum berjalan optimal. Model pengembangan kinerja guru yang diterapkan pada SMA Negeri di Kota Palopo memiliki sejumlah kelemahan, yaitu: (a) perencanaan baru sebatas penjadualan kegiatan serta belum dibuat khusus dan detail berdasarkan analisis kebutuhan; dan (b) pembinaan dan pendampingan belum optimal dan belum fokus pada kebutuhan guru;

3. Pelaksanaan model pengembangan kinerja guru melalui pemberdayaan baru sebatas memenuhi kebutuhan persyaratan kenaikan pangkat. Potensi guru belum dimanfaatkan melalui pemberdayaan, khususnya penelitian tindakan kelas dan musyawarah guru mata pelajaran.

\section{CATATAN AKHIR}

1. John M. Echols dan Hassan Shadily, Kamus Inggeris-Indonesia (Cet. XXVII; Jakarta: PT. Gramedia, 2003), h. 425. Lihat pula Wibowo, Manajemen Kinerja, ed. III (Cet. V; Jakarta: PT. RajaGrafindo Persada, 2011), h. 2. Lihat pula Uhar Suharsaputra, Administrasi Pendidikan, h. 145-146, dan 176.

2. Wibowo, Manajemen Kinerja, h. 86-88.

3. Wibowo, Manajemen Kinerja, h. 89-90.

4. Supardi, Kinerja Guru, Ed. 1 (Cet. 1; Jakarta: Rajawali Pers, 2013), h. 19 dan 23-25.

5. Direktorat Tenaga Kependidikan, Penilaian Kinerja Guru (Jakarta: Direktorat Jenderal Peningkatan Mutu Pendidik dan Tenaga Kependidikan Departemen Pendidikan Nasional, 2008), h. 22.

6. Republik Indonesia, Undang-Undang Republik Indonesia Nomor 14 Tahun 2005 tentang Guru dan Dosen, pasal 20 ayat $b$.

7. Uhar Suharsaputra, Administrasi Pendidikan, h. 145-148

8. Uhar Suharsaputra, Administrasi Pendidikan, h. 148. Lihat pula M. Kadarisman, Manajemen Pengembangan Sumber Daya Manusia, Ed. 1 (Cet. I; Jakarta: Rajawali Pers, 2012), h. 273-274.

9. Wibowo, Manajemen Kinerja, h. 100 dan 324-325.

10. Supardi, Kinerja Guru, h. 21-22.

11. Uhar Suharsaputra, Administrasi Pendidikan, h. 137. 
12. E. Mulyasa, Menjadi Kepala Sekolah Profesional: Dalam Konteks Menyukseskan MBS dan KBK (Bandung: PT. Remaja Rosdakarya, 2004), h. 37.

13. Veithzal Rivai dan Deddy Mulyadi, Kepemimpinan dan Perilaku Organisasi, Ed.3 (Cet.9; Jakarta: Rajawali Pers, 2012), h. 58-61.

14. Departemen Agama R.I, Al-Qur'an dan Terjemahnya, h. 94.

15. Departemen Agama R.I, Al-Qur'an dan Terjemahnya, h. 670.

16. Tim Penyusun Kamus Pusat Pembinaan dan Pengembangan Bahasa, Kamus Besar Bahasa Indonesia (Cet, 9; Jakarta: Balai Pustaka, 1997), h. 662.

17. Muhammad Yaumi, Model Perbaikan Kinerja Guru dalam Pembelajaran (Makassar: Alauddin Press, 2014), h. 135.

18. Wibowo, Manajemen Kinerja, h. 11-12.

19. R. Wayne Mondy, Robert M. Noe, Human Resources Management (New Jersey: Pearson Prentice Hall, 2005), h. 202.

20. Veithzal Rivai, Islamic Human Capital: Dari Teori ke Praktik Manajemen Sumber Daya Islami, Ed.1 (Cet. 1; Jakarta: Rajawali Pers, 2009), h. 298.

21. Raymond A. Noe, John R. Hollenberg, Barry Gerhart, Patrick M. Wright, Manajemen Sumber Daya Manusia: Mencapai Keunggulan Bersaing, Edisi 6-Buku 1, Penerjemah David Wijaya (Cet.2; Jakarta: Salemba Empat, 2011), h. 523.

22. Tim Penyusun Kamus Pusat Pembinaan dan Pengembangan Bahasa, Kamus Besar Bahasa Indonesia, (Cet.9; Jakarta: Balai Pustaka, 1997), h. 503. Lihat pula Sedarmayanti, Membangun dan Mengembangkan Kepemimpinan serta Meningkatkan Kinerja untuk Meraih Keberhasilan (Cet.1; Bandung: Refika Aditama, 2011), h.202.

23. Supardi, Kinerja Guru, Ed.1 (Cet.1; Jakarta: PT. RajaGrafindo Persada, 2013), h. 18-19.

24. Dadang Suhardan, Supervisi Profesional, Layanan dalam Meningkatkan Mutu Pengajaran di Era Otonomi Daerah (Cet. 3; Bandung: Alfabeta, 2010), h. 36-37. Lihat pula Supardi, Kinerja Guru, h. 75.

25. Suharsimi Arikunto, Dasar-Dasar Supervisi. Buku Pegangan Kuliah (Jakarta: Rineka Cipta, 2004), h. 33.

26. Dadang Suhardan, Supervisi Profesional, Layanan dalam Meningkatkan Mutu Pengajaran di Era Otonomi Daerah, h. 47.

27. Suharsimi Arikunto dkk., Dasar-Dasar Supervisi. Buku Pegangan Kuliah, h. 3 dan 45-47.

28. Lesson study sudah berkembang di Jepang sejak awal 1900an. Melalui kegiatan tersebut guru-guru di Jepang mengkaji pembelajaran melalui perencanaan dan observasi bersama yang bertujuan untuk memotivasi peserta didiknya aktif belajar mandiri. Lesson Study merupakan terjemahan langsung dari bahasa Jepang jugyokenkyu, dari dua kata jugyo berarti lesson atau pembelajaran, dan kenkyu berarti study atau research atau pengkajian. Lesson study merupakan study atau penelitian atau pengkajian terhadap pembelajaran. Lihat Rusman, Model-model Pembelajaran: Mengembangkan Profesionalisme Guru, ed. 1. Cet. 1; Jakarta: Rajawali Pers, 2010, h. 384-388. 
29. Hilal Mahmud, Administrasi Pendidikan (Menuju Sekolah Efektif), h. 184-187. Lihat pula Supardi, Kinerja Guru, h. 105-106. Lihat pula Engkoswara dan Aan Komariah, Administrasi Pendidikan (Bandung: Ajfabeta, 2010), h. 230-231.

30. Wibowo, Manajemen Kinerja, h. 414-416.

31. Veithzal Rivai dan Deddy Mulyadi, Kepemimpinan dan Perilaku Organisasi, h. 58-61.

32. Departemen Agama R.I, Al-Qur'an dan Terjemahnya, h. 749.

33. Departemen Agama R.I, Al-Qur'an dan Terjemahnya, h. 389.

34. Departemen Agama R.I, Al-Qur'an dan Terjemahnya, h. 80.

35. Departemen Agama R.I, Al-Qur'an dan Terjemahnya, h. 670.

\section{DAFTAR PUSTAKA}

Al-Quran al-Karim.

Allmon, Barbara dan Sara Freeman. Menjadi Guru Kreatif. Yogyakarta: Golden Book, 2010.

Anggraeni, Mustika. "Pengaruh Manajemen Pembelajaran dan Pengalaman Kerja dalam Upaya Pengembangan kinerjan Guru di SMA PGRI Slawi", Thesis Program Pascasarjana, Program Pascasarjana Universitas Muhammadiyah Surakarta, Surakarta. 2008.

Anonim. Manajemen Berbasis Sekolah. Jakarta: Depdiknas, 2007.

Appelo, Jurgen. Management 3.0: Memimpin Pengembang Agile, Mengembangkan Pemimpin yang Tangkas, Lincah, dan Gesit. Penerjemah Ati Cahayani. Jakarta: PT. Indeks, 2013.

Arcaro, Jerome S. Pendidikan Berbasis Mutu. Yogyakarta: Pustaka Pelajar, 2005.

Arikunto, Suharsimi. Dasar-Dasar Supervisi. Buku Pegangan Kuliah. Jakarta: Rineka Cipta, 2004.

Arikunto, Suharsimi, Suhardjono, dan Supardi. Penelitian Tindakan Kelas. Cet. X; Jakarta: PT. Bumi Aksara, 2011.

Amstrong, Michael. Performance Management. Alih bahasa Tony Setiawan. Yogyakarta: Tugu, 2004.

Armstrong, Thomas. Sekolah Para Juara. Bandung: Kaifa, 2002. . The Best School. Bandung: Kaifa, 2006.

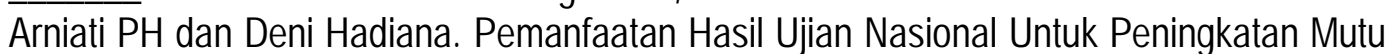
Pendidikan. Jakarta: Puspendik, 2008.

Bacal, Robert. Performance Management, terj. Surya Darma. Jakarta: Gramedia, 2001. . How to Manage Performance. New York: McGraw-Hill Companies, inc., 2004.

Barclay, I., Dann, Z., and Holroyd, P. New Product Development a Practical Workbook for Improving Performance. Oxford: Butterworth Heinemann, 2000.

Bell, Julie. Performance Intelligence at Work. New York: McGraw-Hill Companies, inc., 2009.

Bono, Edward de. New Thinking for the New Millenium. Jakarta: Elex Media Komputindo, 2000.

Braham, Barbara J. Creating A Learning Organization, terj. Zalzulifa. Jakarta: Elex Media Komputindo, 2003. 
Bungin, Burhan. Sosiologi Komunikasi: Teori, Paradigma, dan Diskursus Teknologi Komunikasi di Masyarakat, ed. 1. Cet. 4; Jakarta: Kencana, 2009.

. Penelitian Kualitatif: Komunikasi, Ekonomi, Kebijakan Publik. Dan IImu Sosial Lainnya, ed. 1. Cet. 4; Jakarta: Kencana Prenada Media Group, 2010.

Bush, T., L. Bell \& D. Middlewood. The Principles of Educational Leadership. Second Edition. London: A Sage Publications Company, 2010.

Cascio, Wayne F. Managing Human Resource. New York: McGraw Hill, 2006.

Ciptono dan Ganjar Triadi. Guru Luar Biasa. Yogyakarta: Bentang, 2009.

Collins, J. Good to Great. New York: Harper Collins, 2001.

Covey, Stephen R. The Leader in Me. Jakarta: Gramedia, 2008.

Daft, Richard L. Era Baru Manajemen (New Era of Management), Buku 2, Ed. 9. Penerjemah Tita Maria Kanita, Jakarta: Salemba Empat, 2011.

Danim, Sudarwan. Inovasi Pendidikan dalam Upaya Peningkatan Profesionalisme Tenaga Kependidikan. Bandung: Pustaka Setia, 2002.

Departemen Agama Republik Indonesia. Al-Qur'an dan Terjemahnya, juz 1-30. Surabaya: Mekar Surabaya, 2004.

Depdiknas, Manajemen Peningkatan Mutu Berbasis Sekolah. Buku I. Jakarta: Depdiknas, 2003.

DePorter, Bobbi. Quantum Note-Taker. Bandung: Kaifa, 2004. . Quantum Thinker. Bandung: Kaifa, 2004. . Quantum Learner. Bandung: Kaifa, 2004.

DePorter, Bobbi, Mark Reardon, dan Sarah Singer-Nourie. Quantum Teaching: Mempraktikkan Quantum Learning di Ruang Kelas. Bandung: Kaifa, 2009.

Dharma, Surya. Manajemen Kinerja, Falsafah, Teori dan Penerapannya. Yogyakarta: Pustaka Pelajar, 2005.

Direktorat Pendidikan Menengah Umum Dirjen Dikdasmen Depdiknas. Pedoman Pengembangan Kultur Sekolah. Jakarta: Direktorat Pendidikan Menengah Umum, 2004.

Direktorat Pembinaan Sekolah Menengah Atas Dirjen Manajemen Pendidikan Dasar dan Menengah Depdiknas. Panduan Penyelenggaraan Program Rintisan SMA Bertaraf Internasional (R-SMA-BI). Jakarta: Direktorat Pembinaan Sekolah Menengah Atas, 2009.

Direktorat Tenaga Kependidikan. Penilaian Kinerja Guru. Jakarta: Direktorat Jenderal Peningkatan Mutu Pendidik dan Tenaga Kependidikan Departemen Pendidikan Nasional, 2008.

Djohar. Pendidikan Strategik Alternatif untuk Pendidikan Masa Depan. Yogyakarta: Lesfi, 2003.

Dressler, G. Human Resources Management. Nineth Edition. New Jersey: Upper Saddler River, Prentice Hall, 2003.

Endrotomo. Masalah Kurikulum Berbasis Kompetensi (KBK). Surabaya: P3AI ITS, 2004.

Engkoswara dan Aan Komariah. Administrasi Pendidikan (Bandung: Alfabeta, 2010.

Engkoswara. Paradigma Manajemen Pendidikan Menyongsong Otonomi Daerah. Bandung: Yayasan Amal Keluarga, 2001.

Fahmi, Irham. Manajemen Kinerja Teori dan Aplikasi. Cetakan Ketiga; Bandung: Alfabeta, 2013. 
Fiedler, B. Strategic Management for School Development Leading Your School's Improvement Strategy. London: A Sage Publications Company, 2005.

Gill, R. Theory and Practice of Leasership. New York: A Sage Publications Company, 2009.

Godard, Alain and Vincent Lenhardt. Transformational Leadership, Shared Dreams to Succeed. London: Macmillan Publishers, 2000.

Griffin, Ricky W. Manajemen. Jakarta: Salemba Empat, 2004.

Hoon, Hum Sin. Memenangkan Persaingan Cara Cheng Ho Seni Kolaborasi, Kepemimpinan, Pengelolaan SDM dan Logistik, serta Warisan Iman Sang Laksamana Agung. Terj. Djohan Diaz Tjahjadi. Jakarta: PT. Kompas Media Nusantara, 2012.

Hughes, R.L., R.C. Ginnet \& G.J. Curphy. Leadership Enhancing the Lesson of Experience. New York: McGraw Hill.

Hunsanker, P.L. Training in Management Skill. Upper Saddle River, New Jersey: Prantice Hall, 2002.

Hussey, D.E. How to Manage Organisational Change. London: Kogan Page Limited, 2000.

Iskandar. Metodologi Penelitian Pendidikan dan Sosial (Kuantitatif dan Kualitati). Cet. II; Jakarta: Gaung Persada Press, 2009.

Jalal, Fasli \& Deddy Supriadi (Editor). Reformasi Pendidikan dalam KOnteks Otonomi Daerah. Yogyakarta: Adi Cita, 2001.

Jensen, Eric. Guru Super \& Super Teaching, Lebih dari 1000 Strategi Praktis Pengajaran Super, terj. Benyamin Molan. Jakarta Barat: PT. Indeks Permata Puri Media, 2010.

Kadarisman, M. Manajemen Pengembangan Sumber Daya Manusia, ed. 1. Cet. 1; Jakarta: Rajawali Pers, 2012.

Kasali, Rhenald. Change. Jakarta: Gramedia Pustaka Utama, 2005.

Kirkpatrick, Donald L. Improving Employee Performance. New York: Amacom, 2006.

Lawson, Ken. Performance Review. London: Axis Publishing Limited, 2005.

Lako, A. Kepemimpinan dan Kinerja Organisasi (Isu, Teori, dan Solusi). Yogyakarta: Amara Books, 2004.

Mahmud, Hilal. "Pengaruh Kepemimpinan dan Motivasi Kepala Sekolah terhadap Prestasi Kerja Guru SMA Negeri di Kabupaten Luwu Utara", Thesis Program Pascasarjana, Program Pascasarjana Universitas Narotama Surabaya(UNS), Surabaya. 2007. . Administrasi Pendidikan (Menuju Sekolah Efektif), Edisi Perdana (Palopo: Lembaga Penerbitan Kampus (LPK) STAIN Palopo, 2013.

Maddux, Robert B. Effective Performance Appraisals. California: Crisp Publication, Inc., 2000.

Madya, Suwarsih, Penelitian Tindakan (Action Research), Teori dan Praktik. Cet. 4; Bandung: Alfabeta, 2011.

Manz, Charles C. and Henry P Sims Jr. The Superleadership Learning Others to Lead Themseves. San Fransisco: Berrett-Koehler Publishers, Inc. 2001.

Moleong, Lexy J. Metodologi Penelitian Kualitatif, edisi revisi. Cet. 30; Bandung: PT. Remaja Rosdakarya, 2011.

Muhadjir, Noeng. Metodologi Penelitian Kualitatif. Yogyakarta: Rake Sarasin, 1994.

Mulyasa, E. Menjadi Kepala Sekolah Profesional: Dalam Konteks Menyukseskan MBS dan KBK. Bandung: PT. Remaja Rosdakarya, 2004. 
Neal, James E. Jr. Guide to Performance Appraisals. Ohio: Neal Publication, Inc., 2001.

Noe, Raymond A, John R. Hollenbeck, Barry Gerhart, Patrick M. Wright. Human Resource Management: Gaining A Competitive Advantage, terj. David Wijaya, $6^{\text {th }}$ ed. Jakarta Selatan: Salemba Empat, 2011.

Pardong, A. Tugas Pokok dan Fungsi Pengawas. Jakarta: Badan Diklat Depdiknas, 2003.

Parkay, F.W \& G.J. Hass \& E.J. Ancil. Curruculum Leadership Reading for Developing Quality Educational Program. Nineth Edition. New York: Pearson. 2010.

Republik Indonesia. Peraturan Pemerintah R.I. Nomor 19 Tahun 2005 Tentang Standar Nasional Pendidikan.

. Peraturan Pemerintah R.I. Nomor 19 Tahun 2007 Tentang Standar Pengelolaan Sekolah/Madrasah.

. Undang-Undang Nomor 20 Tahun 2003 tentang Sistem Pendidikan Nasional. . Undang-Undang R.I. Nomor 14 Tahun 2005 tentang Guru dan Dosen.

Rivai, Veithzal, Deddy Mulyadi. Kepemimpinan dan Perilaku Organisasi, ed. 3. Cet. 9; Jakarta: Rajawali Pers, 2012.

Rivai, Veithzal. Islamic Human Capital Dari Teori ke Praktik Manajemen Sumber Daya Islami. Ed.1, Cet.1; Jakarta: Rajawali Pers, 2009.

Robbins, Stephen P., Coulter, Mary. Management. Tenth Edition, Terj. Bob Sabran dan Devri Burnadi Putera. Jakarta: Penerbit Erlangga, 2010.

Rusman. Model-model Pembelajaran: Mengembangkan Profesionalisme Guru, ed. 1. Cet. 1; Jakarta: Rajawali Pers, 2010.

Rustan S. "Pengaruh Kepemimpinan Kepala Madrasah Aliyah terhadap Motivasi Kerja dan Kinerja Guru Bahasa Inggeris di Sulawesi Selatan", Disertasi Program Pascasarjana, Program Pascasarjana Universitas Islam Negeri Makassar, Makassar, 2010.

Sahertian. Konsep Dasar dan Teknik Supervisi Pendidikan. Jakarta: Bhinneka Cipta, 2000.

Sedarmayanti. Membangun dan Mengembangkan Kepemimpinan serta Meningkatkan Kinerja untuk Meraih Keberhasilan. Cet. I; Bandung: PT. Refika Aditama, 2011.

Sharma, S.L. Educational Management, A Unified Approach of Education. New Delhi: Global India Publications, 2009.

Smith, Jane. Empowering People. London: Kogan Page Limited, 2000.

Stuart-Kottze, Robin. Performance. London: Prentice Hall, 2006.

Sugiyono. Metode Penelitian Bisnis. Cet. X; Bandung: Alfabeta, 2007.

. Metode Penelitian Pendidikan, Pendekatan Kuantitatif, Kualitatif. Cet. V; Jakarta: Alfabeta, 2008.

Memahami Penelitian Kualitatif. Bandung: Alfabeta, 2012.

Suharsaputra, Uhar. Administrasi Pendidikan. Cet, I; Bandung: PT. Refika Aditama, 2010.

Suhardan, Dadang. Supervisi Profesional, Layanan dalam Meningkatkan Mutu Pengajaran di Era Otonomi Daerah. Cet. 3; Bandung: Alfabeta, 2010.

Suherman, Atip. "Kontribusi Implementasi Manajemen Partisipatif Terhadap Kinerja Guru dan Terhadap Kegiatan Belajar Mengajar di SMA Negeri 4 Bogor", Thesis Program Pascasarjana, Program Pascasarjana Universditas Gunadarama Jakarta,. 2011.

Supardi. Kinerja Guru. Ed. 1, Cet. 1; Jakarta: Rajawali Pers, 2013.

Supriadi, Dedi. Mengangkat Citra dan Martabat Guru. Cet. 1; Yogyakarta: Adicita Karya Nusa, 1998. 
Susanto, A. B. dan R. Masri Sareb Putra. 60 Management Gems: Applying Management Wisdom in Life. Jakarta: PT. Gramedia Pustaka Utama, 2010

Wade, D. and Recardo, R. Coorporate Performance Management: How to Build a Better Organization Through Measurement-Driven Strategic Allignment. Oxford: Butterworth-Heinemann, 2001.

Wahyudi, Kepemimpinan Kepala Sekolah dalam Organisasi Pembelajar. Cet. I; Bandung: Alfabeta, 2009.

Wibisono, Dermawan. Manajemen Kinerja Konsep, Desain, dan Teknik Meningkatkan Daya Saing Perusahaan. Jakarta: Penerbit Erlangga, 2006.

Wibowo. Manajemen Kinerja, ed. III. Cet. V; Jakarta: PT. RajaGrafindo Persada, 2011. . Manajemen Perubahan, ed. 3. Cet. 3; Jakarta: PT. RajaGrafindo Persada, 2011.

Wiles, J \& J. Bondi. Supervision A Guide to Practice. Second Edition. London: Charles E. Merrill Publishing Company, 2003.

Yaumi, Muhammad. "Pengembangan kinerja Guru Melalui Penerapan Kecerdasan Jamak", Disertasi Program Pascasarjana, Program Pascasarjana Universitas Negeri Jakarta, Jakarta, 2011. . Model Perbaikan Kinerja Guru dalam Pembelajaran. Makassar: Alauddin Press, 2014.

Yulk, G. Leadership in Organization. Seventeenth Edition. Upper Saddler River, New Jersey: Pearson. 2010. 